\title{
US report raises fears over nitrate levels in water
}

Washington. The concentration of nitrates in drinking water in agricultural areas of the United States often exceeds safety standards and is increasing steadily, according to an extensive study carried out by the United States Geological Survey (USGS).

The study made use of 34,000 water samples, and is described by the USGS as the most extensive ever undertaken in the United States. It found that 9 per cent of all domestic water wells, and 21 per cent of samples taken from shallow wells beneath farm land, exceeded the nationally accepted level of $10 \mathrm{mg}$ of nitrates per litre of water. Previous, smaller studies had found only 2.4 per cent of wells exceeded that level.

High levels of nitrates have not been proved to be a hazard for adults. But they have long been regarded as dangerous for infants under six months of age, in which they can cause methaemoglobinaemia, or blue-baby syndrome. The Environmental Protection Agency recommends that parents who use domestic wells test for nitrates, and use bottled water if levels are high.

The survey found that only 1 per cent of public water supplies contained nitrates in excess of the accepted level. But far higher levels were found in domestic wells, on which millions of US households depend.

The study is published at a critical time. Congress is considering revisions to the Safe Drinking Water and Clean Water acts which, environmentalists say, would remove restraints on the use of the bulk fertilizers which, they claim, are the dominant factor behind growing nitrate concentrations.

Environmentalists are already citing the USGS study as evidence that nitrates are a mounting problem in need of a national response. "The findings of this study are most disturbing," says Brian Cohen of the Environmental Working Group, a Washington-based pressure group. "It indicates we have a real national health problem".

But Ron Phillips, a spokesman for the Fertiliser Institute in Washington, says fertilizer use has been "stable" for the past fifteen years. "There are specific areas of the country where the incidence of nitrates is a concern - but the direct link to fertilizer use is very tenuous," he says. Any attempt to solve the problem nationally would be "impractical and overly expensive".

The survey looked at data from 1970 to 1992, and found steadily increasing levels of nitrates in almost all wells where comparable data were available throughout the period. It said the problem was most severe in largely homogenous agricultural areas, such as the mid-west, and less so in areas such as the south-east, where trees were plentiful and land-use varied.

Colin Macilwain

\section{San Diego research body put under microscope on costs}

San Diego. Officials at the University of California at San Diego (UCSD) are investigating how a private foundation partially controlled by faculty members from the School of Medicine spends an annual $\$ 7.2$ million that it receives for research and education.

The inquiry has been going on for almost a year because the foundation has refused to open its books to university auditors. The latter have been checking such foundations at other campuses of the University of California after improprieties were found last year at organizations in San Francisco. They are particularly concerned that attempts may be made to use such foundations to circumvent the university's rules on applying overhead charges to external grants.

Officials of the Medical Education Research Foundation (MERF) in San Diego say that its affairs have been conducted properly, and that, as an independent body, it should be able to protect the privacy of donors of gifts and grants, some of which come from pharmaceutical companies.

Henry Wheeler, a retired head of gastroenterology at UCSD and MERF's president for several years, declined to comment directly, referring inquiries to the foundation's attorney, R. Michael Scarano.

Scarano says MERF has "made substantial contributions" to the university campus and the region's medical community, and wants to continue that role. He adds that the foundation is in "amicable discussions" with the university to resolve the dispute.

Current and former faculty members from the Department of Medicine at the UCSD School of Medicine serve on the board of directors of MERF, which was formed in 1976 and is the largest such foundation at UCSD, with $\$ 16.7$ million in assets.

University officials say they want to examine financial records to ensure there is no abuse of funds, conflicts of interest or improprieties that could reflect badly on the University of California, in whose name some clinical drug trials are conducted.

The auditors are trying to determine

\section{France still follows in Verne's footsteps}

Paris. The Francophone world, already one of the largest consumers of popular science magazines, will next month have another title on its shelves with the launch of Eurêka by Paris-based publisher Bayard Presse.

The monthly 84-page magazine will cover all areas of science, and sell for FF19, about US\$4.00. Bayard has set itself a circulation target of 150,000 .

Eurêka marks the return of Bayard Presse to popular science publishing after a whether UCSD faculty members used university facilities in any of the 25 to 30 clinical trials conducted annually by MERF, whether MERF paid UCSD faculty or staff for work performed on university time, and whether MERF has retained funds intended for UCSD.

John Woods, a vice-chancellor at UCSD, said all other incorporated foundations and support groups at the medical school have cooperated with university auditors. "We are trying to convince (MERF) to turn over information on their operations," he added.

Last year, California's Bureau of State Audits, a watchdog agency, persuaded the San Francisco District Attorney's Office to conduct a criminal investigation to secure the records of two foundations at the University of California at San Francisco (UCSF), where irregularities were alleged.

No criminal charges were filed. But the auditor's subsequent report found conflicts of interest among UCSF employees, payroll records being falsified, university facilities being used for the benefit of personnel, and imprudent spending on gifts and entertainment. The state Attorney General's Office is continuing to investigate the UCSF case.

Ward Connerly, chairman of the finance committee of the University of California Board of Regents, says that he is concerned that foundations like MERF have used their organizations to avoid paying university overhead costs for research. He claims that the foundations "did this to consciously get around university policies".

But MERF attorney Scarano denies such charges. He says that the foundation was trying to "streamline" the grant handling process so that "UCSD faculty would not lose the opportunity" to participate in the clinical drug trials.

According to UCSD officials, an overhead rate of 51 per cent is currently charged on federal grants to the university. UCSD is currently implementing a new policy for grants received from foundations, with a special overhead rate of 19.5 per cent.

Rex Dalton

50-year break. In 1852, the company launched Cosmos, one of the earliest popular science magazines in France. Cosmos, which counted Jules Vernes among its subscribers, was last published in 1940.

A survey carried out by Bayard in association with the pollster SOFRES in June found that 30 million French - about half the population - claim to be interested in science, and that 6 million read science magazines. 